\title{
LIBRARY AND INFORMATION SERVICES FOR THE LEGISLATURE
}

\section{BY}

\author{
PROFESSOR ZAKARI MOHAMMED, FNLA, FNIM \\ DEPARTMENT OF LIBRARY AND INFORMATION SCIENCE \\ AHMADU BELLO UNIVERSITY, ZARIA \\ NIGERIA
}

\begin{abstract}
The paper examines the relevance of information in a society and its connectivity to the emergence of library and information centres. The essence of legislative libraries and information centres particularly their roles in meeting the information needs of the legislators were highlighted. It concludes by advocating for the legislative libraries and information centres to automate their systems, digitize their collection and interconnect with the Internet so that they can provide online services to their clients. It added that the legislators have to be ICT compliant so that they can utilize the services of their libraries and information centres to the fullest capacity.
\end{abstract}

\section{Introduction}

Information can generally be conceived as an idea, experience or anything at all we come in contact with physically or otherwise that adds to our existing knowledge and experience. Such information are said to be vital and necessary as they try to shape our actions and inactions in whatever form to achieve our desired goals and aspirations.

Sources of information from which we can secure and/or access any type of information can include what we read and see from print and non-print media such as from books, newspapers, magazines, television programmes, computers, slides, pictures, maps, etc. It could also be from what we hear from people directly during our contact with them at meetings, class sessions, debates, discussion, sermons, preaching, lectures, etc or indirectly via other media as well as from what we feel, smell, touch or use due to one purpose or the other. Essentially therefore, it could be said that there is no limit to the sources from which we can secure and/or access information as there is also no limit to the type of information we may need or require to be informed on what we need to do, when to do it, how to do it and where to do it. Our limitation as to what type and nature of information we need or access is governed by the purpose for which it is sought.

It is within the above premise that we appreciate the need for the legislators and indeed any other group of people and individuals in any society to access and utilize relevant information to succeed in their endeavours. It is also in the same vain we appreciate the relevance of library and information service as well as documentation and archiving in the provision of variety of information needed to satisfy the yearnings of its target audience.

\section{Library and Information Services}

Libraries and information centres of any type by nature, characteristics and design are expected to acquire, organize and disseminate all available relevant information resources in both print and non-print formats to enable their target clientele access and utilize the needed information to succeed in their respective endeavours they are hired for as well as for their private affairs. Thus, in order to satisfy the information needs of their clientele, libraries and information centres acquire the relevant information resources through direct purchase, exchange, loans, partnership and/or cooperative ventures with other libraries and information centres within and without the environment they exist. It can also be through the formation of consortium of libraries and information centres irrespective of their locations for easy acquisition, processing, and dissemination of both the information resources and their contents for easy access and use.

In order to facilitate easy access and use of the information resources acquired $b y$ the libraries and information centres, they are normally carefully organized and documented according to a given pattern found most suitable and convenient for easy utilisation of the 
clientele. It could be through the use of any of the conventional cataloguing rules and classification schemes or through customized schemes or through 'home-made/institutional made' system so designed to suit the users. This presupposes that there is and there will be no limitation to the nature and format of the information resources to be acquired for access by the legislators. Similarly, there will be no limitation to the time and location of access to the information resources and services. However, the type of strategies, styles, mode of operations and services to be provided to the library and information centre clientele will largely be a function of the type of clientele to be served, their characteristics, interests and other types of their predisposition.

\section{The Legislative Libraries and Information Centres}

The legislative libraries and information centres by their characteristics, nature and design as special libraries are expected to provide any foreseeable services that will make it much easier and convenient for the legislators to access the information needed irrespective of their locations. This is perhaps made much easier today through the automation of their systems, digitization of the content of their information resources, interconnectivity with the Internet and engagement in collaborative efforts with other libraries and information centres within and outside the country for easy access to information resources and services in the collaborating libraries and information centres. However, the gains of collaborative efforts are better achieved when all involved have automated their systems, digitize their collections and are connected to the Internet. The expected results and gains to be derived from the services of the legislative libraries and information centres and indeed from other type of libraries and information centres are better achieved and properly utilized when they have their websites or web pages, as the case might be, for 24 hours access to their contents and services irrespective of the locations of the clientele/legislators and the time of access.

There is no contention in the fact that the legislators are busy group of people engaged in all sorts of legislative functions and activities within and outside their legislative chamber and constituencies aimed at serving the country better so as to ensure that it is strategically located and sustained at greater heights in all respects among other competing nations of the world. This presupposes that they need every bit of information identified to be relevant for the success of their works in their palms or on their finger tips. In effect therefore, the need for the provision of 24 hours online library and information services to the legislators become necessary. On the other hand, it is also presupposed that, as in the case with the library and information centre staff, the legislators and other users of the legislative libraries and information centres must be computer literate or rather, ICT compliant so that they can exploit the online service effectively.

A typical legislative library and information centre should be able to provide easy connectivity between the legislators and the information resources they need irrespective of their locations and time of need. The content of the library and information centre should include all formats of relevant print and non-print documents irrespective of their source. This implies that the library and information centre staff should develop all possible strategies aimed at identifying the existence and location of the needed information resources as well as their acquisition and processing for easy access and use. They are also to seek for viable ways and means of soliciting for information and resources found useful from wherever and even from the legislators themselves for upkeep in the library and information centre. It is these types of efforts that will enable the library and information centre provide variety of information services to the legislators. Thus, in order to succeed in this endeavour, there should be mutual cooperation between the library and information centre and the legislators or rather, the National Assembly especially in the areas of funding and development of the library collection.

It is important for the library to engage in the documentation of information on all socioeconomic, political and other civic activities that takes place in the country for which the legislators may want to refer to at later dates to facilitate their deliberation on such issues. Added to this is the documentation and up-keeping of their proceedings in the Legislative House. Similar efforts should be made on all relevant documents arising from the three alms of government as well as from other public and private sectors of the economy. In the same vain, the library needs to have a profile or database for all legislators and other government functionaries in the other 2 alms of government including those in the government ministries, 
institutions, parastatals and private establishments. Documents emanating from government ministries, institutions, parastatals and private establishments can be of immense importance to the legislators especially in times of legislative proceedings and decision making on vital national issues reflecting their areas of interests in which identified information useful to them are kept for quick reference and access by the legislators and other interested individuals and institutions.

Needless to re-emphasis is the fact that legislative libraries and information centres need to be fully automated and digitized to be able to provide 24 hours online services the legislators need to success. In the $21^{\text {st }}$ century Nigeria, there is no alternative for all types of libraries and information centres from being ICT compliant as the issue of limitations due to time and location of an individual to access information has no place in the contemporary world. In the same vain, the legislative libraries and information centres and indeed other type of libraries and information centres have to be ICT compliant to provide all the needed online library and information services to their patrons Thus, the extent to which they are ICT compliant is predicated by the extent to which they can be able to exploit all the goody-goodies of the ICTbased library and information centres world wide to the overall advantage and benefit to their clientele.

\section{Concluding Remarks}

There is no doubt in the fact that information is vital and necessary for the success of an individual, group of individuals like the legislators and the society at large. Legislative libraries and information centres should endeavour to acquire and organize all available relevant information resources at their disposal through all legal means so as to facilitate easy access and exploitation of their content. Similarly, the libraries and information centres need to automate their systems digitize their collections and interconnect with the Internet so as to provide 24 hours on-line library and information services to their clients. This will also enable the users have access to the content and services of other libraries and information centres world wide. However, it is therefore important that the legislators are ICT compliant so that they can utilize the services of the library and information centre effectively and efficiently irrespective of time and their location. However, there is the need for the legislators and the library authority to provide all the enabling environment which include funds, facilities and other logistics so that the library and information centres can perform better to meet up to their expectations.

\section{Literature Consulted}

Michael B. (1992) Redesigning Library Services: A

Manifesto.http://sunsite.berkeley.edu/Literature/ Library/Redesigning/html.html.

Tennant R (1999) Digital v. Electronic V. Virtual Libraries.

http:/sunsite.berkeley.educ/mydefinitions.html

Ya’u Z.U. (2003) Towards a Virtual Library for Nigeria, http:/Partal.Unesco.org/en/ev.php. 